\title{
Orientalism in G.R.R Martin's a Song of Ice and Fire Deanery's the White Savior
}

\author{
Ghita Mesbah
}

Department of English language and literature "Istanbul Aydin University “ ( Istanbul, turkey)

\begin{abstract}
Identities, cultural differences, feminism, women in power, racism and so on have always been a controversial concept in most contemporary works. Starting with The Arabian Nights, modern fantasy has lately followed the same pattern of depicting the Oriental "Other". The cultural differences between the East and the West have been theorized by many scholars and critics in numerous works of literary modern studies, with reference to Edward Said's book, Orientalism. Said debates that Orientalism is the collateral damage of colonialism, by dominating the East economically, politically and culturally. This collateral damage still exists nowadays; where the patterns of superiority between the West and the East are to be considered. As it is some kind of everlasting unconscious domination, there is no way to dispose of its effects. The West plays the savior's role for the colonized communities; as they are considered helpless and waiting for the support of the West, while facing racial prejudice and religious discrimination
\end{abstract}

The reasons why I have chosen this topic are the exotic representation of the characters' traits and the political and social structures in the series. This is compelling because the world of A Song of Ice and Fire is a secondary one, where reality should be less featured. I argue that this subgenre does not belong to the world of enchantment and magic. Furthermore, the existence of Orientalism within the framework of this subgenre makes the novel series worth examining in this context. The representation of the text makes the texture of fantasy arguable, as the writer still use the same familiar methods to formulate a modern fantasy.

Keywords-The theory of Orientalism, The Eastern world, The Western world, The Orient "other", The improvisation of power.

\section{INTRODUCTION}

Postcolonial studies have been dealing with methods and theories that denote all fields of colonialism and all its dimensions for decades. This continues to postulate its effects on all social patterns until the present. The most important part about these postcolonial studies is the consideration of the relationship between the East and the West that has shaped an identity of the colonized regions and Europe. Colonialism has created a big gap between the East and the West in terms of political strategies, cultural behaviors and economic stability, which in turn creates infrastructural imbalance among the two.

The power that was given to the colonizers over the colonized was shaped into so many social fractures in colonized regions. The term power was considered beneficial for both sides because it included helping the economy, escaping poverty, keeping peace, preserving natural resources and holding order and discipline in the countries. However, the ugly face of power was legitimizing tyranny and political emergence of new forms of liberation and development that caused manufactured territories, societies and economics. The main goal was winning over the minds and hearts of the population.

It is difficult to portray the difference between colonialism and imperialism, as the latter includes control over dependent territories and power and dominance over economics and politics. The colonial project involves the suspension, obedience and integration of ethnic cultures; and most of the time obedience is the key to the success.

In order to ensure continuity and eliminate the "Other's" identity, the colonizer must improvise power and the colonized must abide. Postcolonial thinking is a result of the consciousness of the ancestors to guarantee a new place and space and create instability of other nation's identities.

The colonizers bragged about having good intentions, but good intentions should never come with fear, control and manipulation. The colonial project cannot occur within two different mental maps, so the colonizers need to instill fear in order to expect obedience. As long as obedience 
operates, the situation can only worsen. These created fantasies contain traditional strategic planning that aims to detach the population from its own traditions and attitudes. In order for that to happen, the population must believe that there is no planning from the colonizers and try reinforcing their own, which will lead to achieving particular objectives and advantages.

Edward Said (1979) has defined the phenomena of colonialism to a great extent, and that includes its sources, objectives, and effects. He has also made a critical evaluation of all the aspects of colonialism.

In his article about Orientalism, Sered (1996) explains that:

A rejection of Orientalism entails a rejection of biological generalizations, cultural constructions, and racial and religious prejudices. It is a rejection of greed as a primary motivating factor in intellectual pursuit. It is an erasure of the line between 'the West' and 'the Other'. Said argues for the use of 'narrative' rather than 'vision' in interpreting the geographical landscape known as the Orient, meaning that a historian and a scholar would turn not to a panoramic view of half of the globe, but rather to a focused and complex type of history that allows space for the dynamic variety of human experience. Rejection of Orientalist thinking does not entail a denial of the differences between 'the West' and 'the Orient', but rather an evaluation of such differences in a more critical and objective fashion. 'The Orient' cannot be studied in a nonOrientalist manner; rather, the scholar is obliged to study more focused and smaller culturally consistent regions. The person who has until now been known as 'the Oriental' must be given a voice. Scholarship from afar and second-hand representation must take a back seat to narrative and self-representation on the part of the 'Oriental'. (Sered, 1996)

Through an examination of the essay and a close observation of all the related works of Said and Greenblatt, Sered assumes that colonial narratives reflect a fictional discourse, far from the reality of past events. The nuanced interpretive works, such as G.R.R. Martin's, reusing methodologies and theories that represent people through social and political constraints. These postcolonial thinkers analyze the phenomena of colonization through the damaging strategies of the spectator's mindsets that declares the rejections of the differences of human experiences through different mediums, which may not be easily removable. By the usage of media, social environments, and educational systems, the receivers become blind to the interpretive processes set through those mediums. That includes literature as well, as it is an effective method for the colonizer's systematic manipulation. It certainly is neither easy to reformulate these patterns nor to defend them, but this power relation between the West and East might be studied and deconstructed separately from postcolonial studies. Instead of rejecting foreign thinking, one may try reconciliation with one's self and the "Other's" identity with no greed of pursuit.

Scholars may try new aspects and approaches to better understand indigenous people; they may allow indigenous people to represent themselves in a way that may help both sides by implying the truth about the real identity of each. This might help a whole civilization bring back its core values and mentality, in addition to gaining dignity and personhood once again so that these populations can have a better perceived future. The lost of identity is argued to be due to the colonization of the mind for certain populations; furthermore, the understanding of their psychology made the colonizers capable of performing psychological colonization, something which proved to be quite effective and hard to remove. With reference to the most operative means, the educational system which delivers wrong ideologies about colonialism and its collateral damages must be mentioned.

In light of this phenomenon, the rejection of Orientalism has caused restrictions of intellectual growth, a weakening of the economic systems of the colonized, and an alienation of women. The results of these issues are very destructive for the future of an entire civilization. Maintaining these strategies with the improvisation of power either financial, technological or militant - give rise to an adaptation of the colonizer's attitudes, which expel one's own viewpoint and result into a confusion of one's identity. As the Western colonizers separate themselves from the "Other", especially if there is fear of danger, acceptance of racial distinctions that are depicted as an agreement between the East and the West take place. Even if there is resistance and a struggle for independence in order to gain national existence, it is combated by all means. In addition, as long as one lives within a system of exploitation which makes difficult to succeed, there will 
always be constraints from all sides by the dominant system. These ideas concur with Greenblatt's perspective about the use of power from one level to another.

In explaining further, Greenblatt (2005) states:

In our culture to abandon self-fashioning is to abandon the craving for freedom, and let go of one's stubborn hold upon selfhood, even selfhood conceived as a fiction, is to die. (p.257)

Greenblatt (2005) explains what changes may occur on a certain population through power. As the identity of the "Other" is related to its environment, so the critical practice of colonialism is reinforced through fictionalizing one's belief and creating it according to a set of manipulations by the so-called civilized. These manipulations are necessary to gain power over the psychology and the understanding of the people, which can be more dangerous than propaganda itself, as it bring forth a loss of confidence or of one's own beliefs. The aim of power is to change selfhood and develop a distorted portrait of the colonized, which is transmitted through colonial narratives under the excuse of the people being uncivilized, incompetent and lazy.

Literature is a means to self-affirmation and selfconstruction, as it is relevant to sociological approaches and effectiveness. Greenblatt (2005) uses Renaissance to describe "Narrative absorption" and how it consumes existing power structures through literature, which is related to the study case of the character of Khaleesi as the white savior. Despite her difficult journey, her approach in gaining power is critical. That describes George Martin's perspective on the darkest side of humans and the price people pay in order to gain power.

\section{THE JOURNEY OF DEANERYS TARGARYEN}

Throughout an examination based on the books, Daenerys Targaryen's character's description matches the postcolonial perspectives as she gets swayed by the difficult power position that she finds herself in. Her transformation from a leader to a tyrant, who has been blinded by the greed to achieve higher personal goals, is seemingly accomplished over the bodies of innocent people. Her actual objective is the survival of her blood line and power so that she can have dominance over the Seven Kingdoms; however, she does not consider the destruction her dragons and the unsullied army leave behind. In the book (2011) describes the many struggles she has gone through in her quest for power with a substantial monologue by Daenerys:

I spent my life in foreign lands. So many men have tried to kill me; I don't remember all of their names. I've been sold like a brood mare. I've been shamed and betrayed, raped and defiled. Do you know what kept me standing through all those years in exile? Faith. Not in any gods. Not in myths and legends. In myself. In Daenerys Targaryen. The world hadn't seen a dragon in centuries until my children were born. The Dothraki hadn't crossed the sea, any sea, until me. I was born to rule the Seven Kingdoms, and I will.

Daenerys Storm born of House Targaryen, first of her name and queen of the Andals, is the daughter of a murdered king and, as she believes, the promised princess who will fight against the darkness. She has been called the Mother of Dragons and Mhysa, and she and her brother Viserys are the only Targaryens alive. In addition, she has three dragons that she considers to be her children; gifted to her on her wedding to Khal Drogo.

The silver-haired princess coming from the old blood of Valyria, is a little girl who spent all her life dreaming about her lost childhood and her house in the middle of lemon trees. Daenerys lives with her brother Viserys, who holds a grudge against his sister their mother passed away while she was giving birth to the princess. If Viserys did not feel such hatred for Daenerys, they would have gotten married, since House Targaryen is known for incestuous marriages in order to keep the blood of the family pure. They have spent their lives moving from one place to another as guests, living with different patrons in multiple cities. As Daenerys gets older, the idea of getting back what was stolen from her family, the Iron Throne, grows bigger as well. The reader sees her change from a terrified and abused teenager to a strong woman who lives under the same roof with her vicious brother.

Visery puts the idea of ruling in Daenerys' mind, and the moment she becomes a "woman", he sells her to the leader of a Dothraki Khalasar. The ruthless Khal Drogo buys the princess from her brother; as an exchange, Viserys gets his army of blood-riders to proclaim the Iron Throne. The princess gets raped by the Khal and is forced to live within the so-called uncivilized Dothraki. She becomes the Khaleesi and her brother is killed by her husband. After a while, she loses her husband and unborn child, as she is 
forced to sacrifice one life in exchange for another by using magic.

During her journey, Khaleesi gets exposed to an assassination attempt, a coup d'état from her own people, and a kidnapping operation which ends up making her more powerful. One cannot ignore the instability and the hardships Daenerys goes through during her voyage toward the Iron Throne and her transformation on the way. In $A$ Song of Ice and Fire; all the events of Daenerys' storyline are told through her innocent and naïve perspective. Her miserable situation at the beginning of the book series makes the spectator sympathize with her; and her exposure to so much physical and psychological pain drives her to overrule the Seven Kingdoms, as a reward for her pain. In describing her life, her servant denotes (2011) :

I know that she spent her childhood in exile, impoverished, living on dreams and schemes, running from one city to the next, always fearful, never safe, friendless but for a brother who was by all accounts half-mad... a brother who sold her maidenhood to the Dothraki for the promise of an army. I know that somewhere upon the grass, her dragons hatched, and so did she. I know she is proud. How not? What else was left but her pride? I know she is strong. How not? The Dothraki despise weakness. If Daenerys had been weak, she would have perished with Viserys. I know she is fierce. Astapor, Yunkai and Meereen are proof enough of that. She has survived assassins and conspiracies and fell sorceries, grieved for a brother and a husband and a son, trod the cities of the slavers to dust beneath her dainty sandaled feet. (p.3)

Daenerys endures the bitterness of her life only because of the Iron Throne; her goal is set since the start. Subsequently, the character fits the description of hope for the helpless. Daenerys represents G.R.R. Martin's western perspective about the East and colonization.

The world of A Song of Ice and Fire is a world of politics and violence, with high levels of violence and low ones of magic; and the world of Daenerys is a world of war and terror. Her character's transformation during the storyline is remarkable; she starts as an innocent little princess and becomes a mad tyrant Queen and a power vacuum.
Accordingly, Daenerys goes from being Khaleesi to a mother and then a queen.

The continent of Essos is a description of Orientalist stereotypes, and the presence of Daenerys in Essos as a Westerosi character makes the examination of the character too problematic. This is because it makes it difficult to illustrate the relationship of the character with each continent, as the writer describes her as a protagonist whose actions are crucial and narratives are controversial. She represents the white savior and the white mother for the child-like East.

In her essay, Mhysa or Monster, Hartnett (2016) explains the nature of the narrative of the character as she says:

It is not just the Dothraki who are exoticized, animalized, and dehumanized in Daenerys's journeys across the continent of Essos. It occurs with almost every other race that she comes across. $[\ldots]$ The very mention of these cities and their slave markets inspires terror in Daenerys, yet she has been around slaves at least since her time in the city of Pentos during A Game of Thrones and has owned slaves while living in the khalasar. The assumed danger of these cities has much more to do with their Eastern locales than their slave markets. (p.22)

Her journey across Essos exposes her to different cultures and races, but the readers are only aware of Daenerys' perception of these foreigners. This explains the absence of self-representation of the "Other". She depicts the East as exotic and dangerous, which denotes examples of Orientalism in her character's outlook. Her viewpoint is driven by her Westerosi background, and that shows a colonial fracture between Daenerys and her people. According to Hartnett (2016):

The characters who are not racially coded as white are silenced within the series, for even when the plot occurs in their home country with the majority of people present of their own race, they are never able to represent themselves, but are always represented through Daenerys or another Westerosi point-of-view character. (p. 15) 
Daenerys decides to invade the Seven Kingdoms, starting from Essos, with the intention of releasing people from slavery and making their lands peaceful and developed. At first, she wins the Dothraki tribes on her side. She does so by showing them her dragons and her ability to not be burnt by fire, which the Dothraki may consider a godly power. Afterwards, she moves to Qarth and continues to spread her invasion through all the cities of Slaver's Bay, with the support of her Unsullied army, who are welltrained by their Masters. Her power rises even more with her having three dragons, ships and armies.

The campaign of Daenerys is based upon the Queen's justice. Her viewpoints on justice are fighting slavery, changing an unfair system, and removing from power the Masters who trade women, men, and children in slave markets to serve the elite class of royals, lords, and masters. Daenerys expect that these cities will be freed due to her intervention; however, she believes that this can only be done by bloodshed. This, in turn makes her plans more difficult to pull through, as her mindset about power is not supporting her case at all.

One can notice that in the political interactions between Essos and Westeros, Martin depicts the social and political behavior of Westeros as more developed than the one of Essos.Westeros uses bureaucratic strategies to solve problems, but in Essos bloodshed is the only solution for negotiations to take place. The usage of force to fill the spaces of the "Other" with mystification and terror, proves the Eurocentric thinking of the novel. It is relevant to mention that violence has always been related to being primitive, but the character of Daenerys proves otherwise. She uses her Westerosi background to win back the throne; yet, she uses power and violence to produce a new place and space for herself and her new world.

\section{DEANERYS THE WHITE SAVIOR}

After discussing the major presence of Orientalism in A Song of Ice and Fire, one cannot deny the existence of Colonialism either, as they are related in the postcolonial field. Daenerys uses colonial strategies to win the war, which represent a system of conversion and manipulation behind her social and political behavior and motives. Manipulating military trainings to create unbeatable soldiers, using weapons, and eliminating the "Other's" identity have all been given a particular political utility for her rule and ego, rather than for the state. Since the beginning, her actions have caused harm to her people in one way or another, as she follows the consciousness of her ancestors. A lot of white people believe that they have legitimacy to penetrate any society that is non-western, because it is assumed that they are in need of external intervention to rectify the situation of their national existence.

Daenerys uses traditional strategic planning, which is colonizing and totalitarian, as she immerses herself into the preexisting political, cultural, religious and psychic structures of the natives. She adapts to the Dothraki culture, learns to speak their language, and wears their clothes as a means to serve her purposes. Furthermore, her ideas contradict with those of the Dothraki; yet, she inserts herself into their culture, which she perceives as an ideology, specifically when she thinks that rape is inherent in Dothraki society, but is considered vicious in Westeros. Hartnett (2016) points out:

Daenerys hates wearing the tokar, and even admits to wanting to ban them. While she quickly dons Dothraki or Qartheen dress in order to help gain political advantage, she is unhappy that she has to obey Meereenese customs after she has already conquered. (p.32)

The Dothraki are never meant to serve women; yet, they serve the Queen, as she develops new capabilities to achieve her objectives. These abilities are resisting fire and riding dragons to insert the idea of the Dothraki accepting her rule, which is a manipulation of social norms and detachment from traditions and stability.

Deanery's image from a leader's wife to the Queen of the Seven Kingdoms makes her act Eastern to increase her power. She even uses magic to save her husband, something which is against her morals, as a selfaffirmation tactic to reinforce her position as a brave ruler who accepts all exotic cultures and its beliefs. Thus, when she felt a threat toward her Western identity, she ruled over the blood riders by creating uncertainty about their identities, as a psychological weapon, and dragons, as a physical one.

As the existing power structures can be fictionalized by a colonizer, Daenerys does not lose her chance to do so with the Dothraki people. It is easier for her to construct a new identity for the "Other", that goes along with all the developed standards of Western justice and mercy..

Daenerys labels her campaign as a merciful and freedomseeking one. However, she uses force to gain the Dothraki's trust to fight by her side. This does not mean that these tribes are naïve, but rather ignorant enough to believe into magic, dragons and supernatural powers. On the other 
hand, the people of Westeros did not believe in the Mother of Dragons coming toward Westeros to proclaim the throne. As the Dothraki people are hard to convince, Daenerys uses her dragons to gain their alliance. In addition, burning all the other Dothraki Khals after they refuted her, made her position much stronger.

We can notice here that freedom and peace have disappeared and a system of exploitation and tyranny has begun. This is what Greenblatt (2005) explains as the western mode:

There are periods and cultures in which the ability to insert oneself into the consciousness of another is of relatively slight importance, the object of limited concern; others in which it is a major preoccupation, the object of cultivation and fear. Professor Lerner is right to insist that this ability is a characteristically (thought not exclusively) Western mode, present to varying degrees in the classical and medieval world and greatly strengthened from the Renaissance onward; he misleads only in insisting further that is an act of imaginative generosity, a sympathetic appreciation of the situation of the other fellow. For when he speaks confidently of the "spread of empathy around the world," we must understand that he is speaking of the exercise of Western power, power that is creative as well as destructive, but that is scarcely ever wholly disinterested and benign. (p.5)

Daenerys heads to Meereen and Astapor to precede her road toward the throne, but this time she adapts her Westerosi morals to end slavery in the cities of Essos, as a strategy of liberation. She believes that this matter needs her intervention. As Hartnett (2016) points out:

Daenerys gains power, but why does she feel the need to gain it? After Drogo's death, she travels to Yunkai, then Astapor, then Meereen; each location is a stop on her imperialistic journey. After she has won the city, often through under-handed means, she either removes the governmental leaders and selects a new ruling council-as she does in Yunkai and Astapor-or proclaims herself queen and rules the city herself-as in Meereen: "No one was calling her Daenerys the conqueror yet, but perhaps they would" (Martin, Storm 979). (p.53)

Even though Daenerys considers slavery immoral, she does not offer complete freedom; instead she is allowing people to be free except when it comes to her. Thus, the people move from one form of oppression to another, in other words, from having masters to having a queen. Giving the people freedom would violate her sense of justice and control. Daenerys proclaims herself the ruler and starts to get rid of the other leaders. Additionally, her soldiers maintain the peace and discipline and forbid slavery.

As a liberator Daenerys turns from a queen to a colonizer for her rightful golden crown. Her colonization of Essos under the pretence of spreading freedom represents the high morals of Westeros and depicts the inferiority of Essos, as a continent where slavery is legal. Having lived in Essos for a long period of time should be enough to shape her beliefs; yet, she chooses to act as a Westerner rather than an Easterner, as an appropriate method of gaining power and feeling superior enough to play the role of the western white savior. On the other hand, by ending slavery, Daenerys weakens the continent's economic system and puts them in danger of poverty, debt and a possible risk of civil war, which are considered elements that can destroy whole civilizations. Hartnett (2016) expresses this further:

Daenerys has weakened both the country and its people by removing their sole industrial product-slaves. Ignoring the cruelty inherent in slavery, it would be a mistake to overlook that Daenerys tanks Meereen's trade by not scrutinizing their economic position and blindly forcing Western morals onto this entirely different culture. (p.59)

In Meereen, Daenerys tries to restore the whole city with new rules, a new lifestyle and modern culture. She starts teaching young pupils her native language, Valyrian, In addition, she changes the symbol of the city over the pyramids and makes her own, next to her dragons residing on the top for everyone to see. These actions leave people stuck between traditions and modernization, which of course creates a huge change of principles for a whole civilization. Greenblatt calls it 'fashioning', which means making one's identity similar to the one of the colonizer to construct a neat identity fitting to the new world and 
standards to go along with the developed lifestyle of Westeros.

Throughout the position of the colonized cities, the new forms of controlling those preexisting social structures have created resistance and self-esteem issues from the people. This made the people ask for the return of slavery, as they found it more helpful than the freedom that the queen gave them. This shakes the sense of power of the colonizer. People of Meereen started showing their disapproval and resistance by separating themselves from her path and living their lives as during the preexisting system. The Sons of the Harpy could not accept the imperialist strategies of the queen, so they become violent.

Hartnett (2016) states:

In addition to her idealization of Westeros, Daenerys fulfills some of the basic characteristics of colonizers. After the colonizer has conquered the colonized, "the few material traces of that past are slowly erased, and the future remnants will no longer carry the stamp of the colonized group. The few statues which decorate the city represent (with incredible scorn for the colonized who pass by them every day) the great deeds of colonization" (Memmi104). (p.50)

\section{IMPROVISATION OF POWER IN ESSOS}

This tension between the Harpies and the Queen made violence necessary to achieve personal gain, which explains that violence is a psychological necessity to feel superior over the other, and put them into the status of dangerous outlaws. Furthermore, resistance is caused by the refusal of both the colonized and the colonizer. In this case, the colonizer has two options: Either to withdraw or face the consequences of continuing the war.

As Daenerys obtains more power than her own people, she does not retreat her desirable decisions to help the helpless. Instead, she gains more power to exploit the weak and frighten them of getting exposed to her dragons. The reason behind this is the lack of unity with Easterners, which makes the case less difficult for the colonizer to implement their democratic, western strategies that might raise radical groups, as is the case of the Harpies in the world of A Song of Ice and Fire. Therefore, losing one city on the expense of gaining control over the Seven Kingdoms is not substantial for Daenerys, as her vision is much bigger than what it seems. Thus, winning more alliances, even if it requires violence, is a must. In order to win a bigger prize, one must accept the risk of having slight collateral damage.

In his essay, Greenblatt (2005) explains the position of the colonized within the struggle of colonization. The colonized may choose obedience or resistance, knowing that obedience offers more space for the colonizer to improvise power over the state. The silence of the oppositional "Others" may affect the path of colonization in the same way that words do. In A Song of Ice and Fire, the colonizer tries to efface the identity of the colonized by various strategies of making the original paradigms disappear and replacing them with developed, disciplinary paradigms that may produce either something the colonizer desires, obedience, or something they fear, resistance. However, the colonized usually prioritize keeping their origins and fighting for their beliefs, instead of submitting their identities at the end.

\section{According to Hartnett (2016),}

Astapor has devolved because Daenerys, in her attempt to further her quest and incidental liberation of the slaves, has left a power vacuum soon filled by a dictator who quickly returns the city to its previous slaving ways. Now, it is the former slaves who rule and the former Masters who are in chains. She has helped the city; she has merely shifted the power balance. (p.66)

The people's objection of Daenerys' colonial project and her refusal to withdraw from the cities cost her people their lives. While spreading chaos and terror, the Masters killed many children as a sign of disagreement of the new system, but Daenerys did not avenge them. Instead, she was only concerned about keeping her army fed, so that they would be strong enough to fight by her side. This explains the moral confusion of the colonial process, which is already based upon western morals. Inside the free cities of Slaver's Bay that she handed to the peace keepers of her army to lead, chaos started and civil war rose up. This liberation has not helped the cities; it only brought back slavery and a worse system of ruling.

The character of Daenerys unconsciously represents the white savior in helpless lands. She fits the portrait of the colonizer as discussed by many critics; her vision of conquest, her motives and strategies attribute the imperialist mindset. While keeping track of her course toward the throne, a reader cannot decline the entity of colonialism and imperialism that Martin adopts in the 
representation of the character. Daenerys' point of view is filled with exoticism, violence, manipulation and mobility. AsGreenblatt (2005) has mentioned in his statements, nonwestern cultures that intimidate the stereotypes about the Orient might have been avoided, specifically in this fantasy genre, as it may influence the reader's ideologies about Easterners.

Adaptation, imitation, and derivation of the forms and structures appear in the character's way of building the tactics that she executes to reach her goals. Her colonial narratives give a self-oriented portrait about indigenous people of foreign lands, where they are illustrated as complicated and violent savages. This explains the huge difference between being a Westerner and an Easterner experiencing the path of colonialism.

\section{CONCLUSION}

A Song of Ice and Fire is a combination of several cultural and social archetypes, including Orientalism, colonialism, imperialism and even capitalism. Keeping the Western vision on Easterners the same through centuries makes Martin's work similar to the previous contemporary works in terms of adapting a negative manner to cement the imagination of the readers. Yet, Martin's intentions about these representations are still gray. Using these traditional strategic ideas of the ancestry of Orientalism's invention, in the boundaries of the fantasy genre, and showing their dark side at the same time, troubles the point of view of the reader. Nevertheless, the existence of such subjects of in a modern work makes it familiar and typical, confirming Edward Said's contention about framing Western superiority; however, the element of magic and enchantment has nuanced these interpretations within the storyline of the magical world of A Song of Ice and Fire.

The political perspective of a novel may represent the political mindset of a writer and their opinion about the governing systems of different nations; but through the examination of A Song of Ice and Fire, one may find elements of colonization and Orientalism, in addition to imperialism. Throughout this study of A Song of Ice and Fire, with emphasis to the character of deanerys, the existence of Orientalism has revealed hidden capitalist figures that exploit the whole plan of ruling the Seven Kingdoms. From East to West, Bravos is considered the most powerful and wealthiest city of the world; the place that holds the center of power, the Iron Bank. During Queen Daenerys' journey, all events and incidents are wellrevised plans that benefit the Iron bank, the most powerful institution in the two continents.
The monolithic structure of the Iron bank cannot be avoided, as they fund wars, science, education and the ruling regimes, so the realm stays under its control in order to be sure about where and to whom to invest.

\section{REFERENCES}

[1] A Game of Thrones by George R.R. Martin book review. (2019). Fantasy Book Review. Retrieved from https://www.fantasybookreview.co.uk/George-RR-

Martin/A-Game-Of-Thrones.html

[2] Akchurina, V. (2019, March 28). On the Power of Improvisation. DOC Research Institute. Retrieved from https://doc-research.org/2018/08/power-improvisation/

[3] Ali, K. (2018). Review: Race and Popular Fantasy Literature: Habits of Whiteness, by Helen Young. Journal of Popular Romance Studies. Retrieved from jprstudies.org/2018/10/review-race-and-popular-fantasyliterature-habits-of-whiteness-by-helen-young/

[4] Attewell, S. (2013, December 22). Chapter-By-Chapter Analysis - Daenerys I. Race for the Iron Throne. Retrieved from

https://racefortheironthrone.wordpress.com/2012/03/26/chap ter-by-chapter-analysis-daenerys-i/

[5] Baradan, S. N. (2015). Re-VisitingOrientalism: On the Problem of Speaking for the Orient.ColoradoState University.

Retrievedfromhttps://mountainscholar.org/bitstream/handle/ 10217/167087/Baradan_colostate_0053N_13054.pdf?sequen ce $=1 \&$ is Allowed $=y$

[6] Beaudoin , M. A. (2019). Challenging Colonial Narratives. Tucson, Arizona: University of Arizona Press (UA Press). DOI: 10.2307/j.ctvf3w2bb

[7] Bose, S. P. (2011). Regional Histories and Their Possibilities. Ashadeep Kolkata.

[8] Cunningham, J. (1997). Shakespeare's Tragedies and Modern Critical Theory. Vancouver, Canada: Fairleigh Dickinson University Press.

[9] DaenerysTargaryen. (2019). Game of Thrones Wiki. Retrieved from https://gameofthrones.fandom.com/Daenerys_Targaryen

[10] Dascal, M. (2004). Colonizing and Decolonizing Minds. Philpapers. $\quad$ Retrieved from https://philpapers.org/rec/DASCAD

[11] Davis, C. (2015). Embracing Alterity: Rethinking Female Otherness in Contemporary Cinema. University of British Columbia. Retrieved from https://open.library.ubc.ca/cIRcle/collections/ubctheses/24/it ems $/ 1.0166660$

[12] Fantasy's 'Othering' Fetish. (2013, June 18). PhendersonDjeli Clark. Retrieved from https://pdjeliclark.wordpress.com/2013/06/18/fantasysothering-fetish/\#more-1872

[13] Flood, A. (2016, August 5). Game of Thrones: An Epic Publishing Story. The Guardian. Retrieved from https://www.theguardian.com/books/2016/aug/05/game-ofthrones-an-epic-publishing-story-george-rr-martin 
[14] Frankel, V. E. (2014). Women in Game of Thrones: Power, Conformity and Resistance. Jefferson, North Carolina: McFarland \& Company.

[15] Goldberg, D. (2011, October 23). In Defense of Hippies. Dissent Magazine. Retrieved from https://www.dissentmagazine.org/online_articles/in-defenseof-hippies

[16] Greenblatt, S. (2005). Renaissance Self-Fashioning: From More to Shakespeare. Chicago, Illinois, United States: University of Chicago Press.

[17] Guxens, A. (2012, October 7). George R.R. Martin: "Trying to PleaseEveryone Is a Horrible Mistake" [In person]. Adria's

News. Retrievedfromhttp://www.adriasnews.com/2012/10/georger-r-martin-interview.html

[18] Hardy, M. (2015). Game of Tropes: The Orientalist Tradition in the Works of G.R.R. Martin. International Journal of Arts \& Sciences, 08(01), 409-420. Retrieved from https://ww.researchgate.net/publication/284564009_Game_o f_Tropes_the_Orientalist_tradition_in_the_Works_of_GRR Martin

[19] Hartnett, R. (2016). Mhysa or Monster: Masculinization, Mimicry and the White Savior in A Song of Ice and Fire. Florida Atlantic University. Retrievedfromhttps://fau.digital.flvc.org/islandora/object/fau \%3A33682/datastream/OBJ/view/Mhysa_or_Monster_Mas culinization_Mimicry_and_the_White_Savior_in_A_Song _of_Ice_and_Fire.pdf

[20] Hassan, I. (1987). Toward a Concept of Postmodernism. In The Postmodern Turn. Columbus, Ohio: Ohio State University Press.

[21] History of Survivance: Upper Midwest 19th-Century Native American Narratives. (n.d.). Colonial Narratives DPLA, Digital Public Library of America. Retrieved from https://dp.la/exhibitions/history-of-survivance/colonialnarratives

[22] House Lannister (Complete Guide to Westeros). (2019). Game of Thrones Wiki. Retrievedfromhttps://gameofthrones.fandom.com/wiki/Hous e_Lannister_Complete_Guide_to_Westeros)

[23] Iron Bank of Braavos. (2019). Game of Thrones Wiki. Retrieved from https://gameofthrones.fandom.com/wiki/Iron_Bank_of_Braa vos

[24] Ismail, F. (2009). Others and Spaces in Fantasy Otherworlds. Mousaion, 27(01), 191-208. Retrieved from https://journals.co.za/content/mousaion/27/si-1/EJC78977

[25] Jennings, D. (2011, July 14). In a Fantasyland of Liars, Trust No One, and Keep Your Dragon Close. The New York Times. Retrieved from https://www.nytimes.com/2011/07/15/books/a-dance-withdragons-by-george-r-r-martin-review.html

[26] Khan, R. (2012, May 25). An Orientalist Fantasy. Discover. Retrieved from blogs.discovermagazine.com/gnxp/2012/05/an-orientalistfantasy/\#.XDEDOVwzbIV
[27] Kohn, M. and Reddy, K. (2017). Colonialism. The Stanford Encyclopedia of Philosophy. Retrieved from https://plato.stanford.edu/archives/fall2017/entries/colonialis $\mathrm{m} /$

[28] Kumar, A. M.P. (2003). Colonial Narrative: Condescending and Bemoaning. In Colonial Narrative on India Counter Narrative and Colonial Experience in Gandhian Era. Kerala, India: University of Calicut.

[29] Laurie Penny on Game of Thrones and the Good Ruler Complex. (2012, June 4). New Statesman. Retrieved from https://www.newstatesman.com/blogs/tv-andradio/2012/06/game-thrones-and-good-ruler-complex

[30] Lawrence, A. (2016). The Colonizer and the Colonized in the Post-colonial. THE DECOLONIZER. Retrieved from thedecolonizernewsletter.blogspot.com/2016/01/thecolonizer-and-colonized-in-post.html

[31] Maiello, M. (2014, May 12). How Real Is the Iron Bank in 'Thrones' Anyway? Esquire. Retrieved from https://www.esquire.com/entertainment/tv/news/a28697/iron -bank/

[32] Malinen, M. (2006). Tom Clancy and Orientalism: Arabs and Muslims in the Contemporary Techno-thriller Novel. UNIVERSITY OF JYVÄSKYLÄ.

[33] Martin, G. R. R. (1999). A Clash of Kings. New York, NY: Bantam Books.

[34] Martin, G. R. R. (2011). A Dance with Dragons. New York, NY: Bantam Books.

[35] Martin, G. R. R. (2013). A Storm of Swords: Book Three of A Song of Ice and Fire. New York, NY: Bantam Books.

[36] Martin, G. R. R. (2017). A Feast for Crows. New York, NY: Bantam Books.

[37] Martin, G. R. R. (2017). A Game of Thrones. New York, NY: Bantam Books.

[38] Mufti, A. R. (2010). Orientalism and the Institution of World Literatures.Critical Inquiry, 36(3), 458-493. University of Chicago Press. DOI: 10.1086/653408

[39] Nandi, R. (2011). Colonial Narratives and the Local Writings: Developing History and Ethnography in PostIndependent North Bengal. In SeshadriProsad Bose (Ed.), Regional Histories and Their Possibilities.Ashadeep Kolkata. $\quad$ Retrieved from https://www.academia.edu/7567985/Colonial_Narratives_an d_the_Local_Writings_Developing_History_and_Ethnograp hy_in_post-independent_North_Bengal?auto=download

[40] Nodelman, P. (1992). The Other: Orientalism, Colonialism, and Children's Literature. Children's Literature Association Quarterly, 17(01), 29-35. John Hopkins University Press. DOI: $10.1353 /$ chq.0.1006

[41] Öktem, Ö. (2019). Introduction: Re-Orienting Gender and Islamic Alterity in Early Modern English Drama. English Studies, $100(2), \quad 1-16 . \quad$ DOI: 10.1080/0013838X.2018.1555980

[42] Onbelet, L. (n.d.). Imagining the Other: The Use of Narrative as an Empowering Practice. McMaster University. Retrieved from https://www.mcmaster.ca/mjtm/3-1d.htm

[43] Ordonez, M. (2012). Monster, Magic and the Andal Response: Orientalist Imagining and Engaging the "Others" 
in Game of Thrones (Book1). Academia. Retrieved from https://www.academia.edu/4845433/Monster_Magic_and_th e_Andal_Response_Oriental_Othering_in_Game_of_Throne s_Book_1

[44] Outline of Stephen Greenblatt's 'The Improvisation of Power' from Renaissance Self-Fashioning. (1980). University of Chicago Press. Retrieved from cola.calpoly.edu/ smarx/courses/204/Othello/greenoth.html

[45] Rékasi, E. (2012). Game of Thrones - What a Post-Modern Way of Thinking!.Academia. Retrieved from https://www.academia.edu/3651139/Game_of_Thrones__a_Postmodern_Way_of_Thinking_

[46] Rick, D. W. (2013, February 13). Building Walls and Taking the Black: The Border Narrative of A Song of Ice and Fire. SWTX PCA Conference. Retrieved from https://www.academia.edu/9353608/Building_Walls_and_T aking_the_Black_The_Border_Narrative_of_A_SONG_OF_ ICE_AND_FIRE

[47] Roberts, J. (2013). The Lands of Ice and Fire - the Maps of Game of Thrones. Fantastic Maps. Retrieved from www.fantasticmaps.com/the-lands-of-ice-and-fire/

[48] Said, E. (1979). Orientalism. New York, NY: Random House Publishing (Vintage Books).

[49] Said, E. (2003, August 2). A Window on the World. The Guardian. $\quad$ Retrieved from https://www.theguardian.com/books/2003/aug/02/alqaida.hi ghereducation

[50] Said, E. (2003, March 20). Always on Top: From Birmingham to Jamaica. London Review of Books, 25(06), 3-6. Retrieved from https://www.lrb.co.uk/v25/n06/edwardsaid/always-on-top

[51] Schroeder, J. A. Jr. (2016). A Medievalist Point of View on George R. R. Martin's A Song of Ice and Fire: Power and Women: An Examination of DaenerysTargaryen. Culminating Projects in English, 57. Retrieved from https://repository.stcloudstate.edu/engl_etds/57

[52] Sered, D. (1996). Orientalism. Postcolonial Studies at Emory Pages. Retrieved from https://scholarblogs.emory.edu/postcolonialstudies/2014/06/ 21/orientalism/

[53] Shabrin, M. Z. (2014). Reexamining Orientalism in George R. R. Martin's A SONG OF ICE AND FIRE. University of Indonesia. Retrieved from lib.ui.ac.id/file?file=digital/20369007-MK-

Mila\%20Zuliana\%20Shabrin.pdf

[54] Shortall, R. (n.d.). The Secret History Of The Iron Bank Of Braavos. Ranker. Retrieved from https://www.ranker.com/list/everything-you-need-to-knowabout-the-iron-bank-of-braavos/rebecca-shortall

[55] Sladiková, L. (2015). Reality in George R. R. Martin's A Song of Ice and Fire. Masaryk University. Retrieved from https://is.muni.cz/th/p5fu7/thesis.pdf

[56] Smoke on the Water. (2016, July 26). Wars and Politics of Ice and Fire. Retrievedfromhttps://warsandpoliticsoficeandfire.wordpress. com/category/asoiaf-analysis/page/2/
[57] Staszak, J. F. (2008). OtherlOtherness. In Kitchin\& Thrift (Ed.). International Encyclopedia of Human Geography. Oxford: Elsevier Science.

[58] Stokes. (2012, May 30). It Is Known - Game of Thrones, the Orient, and Conventional Wisdom. Overthinking It. Retrieved from https://www.overthinkingit.com/2012/05/29/game-ofthrones-orientalism/

[59] The History of Banks. (n.d.). Worldbank.org.ro. Retrieved from https://www.worldbank.org.ro/about-banks-history

[60] The Queen's Justice. (2019). Game of Thrones Wiki. Retrieved

from https://gameofthrones.fandom.com/wiki/The_Queen\%27s_J ustice

[61] The Rise Of The Hippy Culture In 1960S Challenges The Cultural. (2017, March 31). Bartleby Research. Retrieved fromhttps://www.bartleby.com/essay/The-Rise-Of-TheHippy-Culture-In-F3BY6V3L8E7W

[62] Tiné, H. F. (2010). Postcolonial Studies. EGO, The Institute of European History. Retrieved from iegego.eu/en/threads/theories-and-methods/postcolonial-studies

[63] .Veeser, H. A. (1989). The New Historicism. Scribd Retrieved

From https://www.scribd.com/doc/124031217/Harold-AramVeeser-The-New-Historicism

[64] Vike, M. (2009). The Familiar and the Fantastic: A Study of Contemporary High Fantasy in George R. R. Martin's A Song of Ice and Fire and Steven Erikson's Malazan Book of the Fallen. Riga, Latvia: VDM Verlag.

[65] Wilcox, S. (2014, April 28). Women of Westeros. Academia, 1-11. Retrieved from https://www.academia.edu/30038879/Women_of_Westeros

[66] Woronoff, J. (2005). Historical Dictionaries of Literature and the Arts. Lanham, Maryland: The Scarecrow Press, Inc. 